\title{
Impact of Exchange rate volatility on FDI in Pakistan
}

\author{
Samran Yousaf ${ }^{1,}$ Iqra Shahzadi $^{2,}$ Bushra Kanwal ${ }^{3,}$ Supervisor: Marria Hassan ${ }^{4}$ \\ Business Administration, University of Gujrat, Wazirabad, Pakistan \\ Business Administration, University of Gujrat, Gujranwala, Pakistan \\ Business Administration, University of Gujrat, Gujrat, Pakistan \\ International Islamic University, Islamabad
}

\begin{abstract}
The main objective of our study is to determine the relationship of FDI with exchange rate volatility exchange rate and inflation. There are large numbers of FDI determinants but exchange rate is one of reflective determinant. Exchange rate extremely volatile due to its frailty to adopt the changes in international and domestic investment. In our study, we use time series data for FDI, exchange rate volatility, exchange rate, government consumption and domestic credit from 1980 to 2011 for Pakistan. Different time series econometrics techniques (volatility analysis, normality test, $P$, unit root test) have been used for analysis. Results demonstrate that exchange rate volatility and inflation deter FDI while exchange rate has positive relationship with it.
\end{abstract}

Keywords: FDI, exchange rate, exchange rate volatility

\section{Introduction}

FDI as the figurative investment restructures the world of finance. The volume of FDI is elevated with revenge from the last two decades. Policy makers of most countries particularly developing countries attracting the FDI is credibly rhetoric. Vicious circle of poverty is just like wickedness for the developing countries. For smash the vicious circle of poverty it is to be complement the domestic capital by accomplishes the minimum level of investment. Developing economies have a problem of scarcity of capital therefore these countries attracting more FDI.

The inflation rate, GDP and the real exchange rate demonstrate excessive volatility in developing countries (Easterl, Islam and Stiglitz, 2000). The surplus of volatility of above discussed macroeconomic variables affects not only the level and volume of international trade, but it also affects the flow of FDI and the level of private investment (Dhakal et al, 2010). There are many studies in literature that explore the relationship of exchange rate volatility with private investment (Bhandari and Upadhyaya, 2008; Pradhan et al, 2004). Exchange rate volatility can influence the competitiveness of corporations in different countries. In fact, it can probably have a positive or negative effect. On the one side, firms face the risk intrinsic in volatile exchange rate. On the other side, firms have the opportunities to shift their production elsewhere to enjoy the advantage of lower cost (Goldberg Kolstad, 1995).

In our paper, we broaden the literature on the relationship of exchange rate volatility with foreign direct investment (FDI) in Pakistan. The exchange rate of Pakistan has a great compact of variability.

Theoretically, the multiplier-accelerator model describes that with the help of income and interest rate, changes in investment or capital stock can be determined. There are also many factors which are used to determine the investment; these factors include government policy, risk and profitability or expected returns of investment.

There are many frameworks exist which are used for analyzing the determinant of foreign investment. FDI depends upon non-economic factors such as macroeconomic variability, political instability and risk. FDI is future looking activity which is based on the expectations of investors for future returns and confidence to place these returns. These variables enhance the uncertainty and slow down the investment. Variability of exchange rate has many disadvantages. First, if price elasticity is low down then depreciation of exchange rate effects could be vicious. Second, it is usually related with exchange rate risk and uncertainty. Third, volatility in exchange rate could result in considerable decrease in the value of assets invested and future profits earned by the investment in host country. Lastly, speculation of exchange rate movements can threatening hence, enforcing losses in economic efficiency and stimulating avoidable capital gate way. Chakrabarti (2001) stated negative relationship of FDI flows from the US to twenty OECD (Organization for Economic Co-operation and Development) countries and exchange rate volatility. Udoh and Egwaikhide (2008) found high volatility of inflation and exchange rate. Volatility in exchange rates and inflation raised risk and uncertainty faced by foreign investors, thus negatively affect the foreign investment in a country. 


\section{Literature Review}

Del Bo (2009) reports an analyze the consequences of exchange rate and institutional instability on the intensity of FDI flows involving developed and emergent countries in Italy, by presenting an pragmatic investigation on a group of countries from 1970 to 2006. This study includes exchange rate volatility, institutional risk, GDP and openness as independent variables and FDI as dependent variables by using the GARCH (Generalized Auto Regressive Heteroscedastic) modeling. The findings of this study are that political risk and exchange rate volatility reduces the FDI flows.

Lemi and Asefa (2001) studied the impact of exchange rate and price uncertainty and political instability on the inflow of FDI including the selected African economies in Ethiopia. Volatility of real exchange rate reduces the inflow of FDI. But combined with political instability, it significant positive impact on the flow of FDI. The data was taken of selected African economies from 1975 to 1997. Real exchange rate, inflation and political instability as independent variables, this study showed the impact on dependent variable, FDI by using the methodology of ARCH (Autoregressive Heteroscedastic) and GARCH. The result concludes for the real exchange rate is statistically insignificant.

Udoh and Egwaikhide (2008) inspect that how exchange rate volatility and inflation uncertainty affect the FDI in Nigeria by covering the period of 1970 to 2005. FDI used as dependent variable while inflationary volatility, exchange rate volatility, political instability and many other macro economics variables used as independent variables. Inflation uncertainty and exchange rate volatility was calculated by using the GARCH model. The results concluded that inflation uncertainty and exchange rate volatility negatively affect the FDI in Nigeria. These variables also effect significantly to the FDI.

Ellahi (2011) examine the impact of exchange rate volatility on foreign direct investment for the sample of Pakistan economy by applying modern and robust technique of Auto Regressive Distributed Lag (ARDL) modeling approach. In this study data covering the period of 1980 to 2010. They take foreign direct investment as dependent variable and real gross domestic product (GDP), trade openness, real exchange rate, capital account balance, and volatility of exchange rate as independent variables. The result shows that exchange rate volatility has negative impact on FDI inflow in short run and has positive impact in long run. Further the study shows the structural adjustment program has positive and favorable impact on FDI in short run.

Osinubi et al (2009) the objective of this paper to) inspects the impact of exchange rate volatility on foreign direct investment for a sample of Nigeria economy, by applying an Error Correction Model (ECM). The data collected from the period 1970 to 2004. They take a foreign direct investment (FDI) as dependent variable, while exchange rate, exchange rate volatility, interest rate and real gross domestic product as independent variable. This study finds the positive and significant results of their estimated model. So exchange rate volatility has positive and significant impact on FDI.

Kiat (2010) try to find out the effect of inflation and exchange rate on FDI and the relationship of these variables with economic growth. Extensive study was done within the South African economy and detailed analysis was done for 30 countries' economy. The aim of the study is to determine the relationship of economic growth, FDI inflow, inflation and exchange rate. Sample surrounded economic data of 30 countries across more than two decades. Linear regression analysis used on economic data to determine the relationship of FDI inflows, inflation exchange rate and economic growth. Findings of this study concluded that FDI chases economic growth while inflation negatively affects the FDI and exchange rate positively. In case of inflation, the relationship is more significant in developed economies.

Dhakal et al (2010) used panel data to observe the impact of exchange rate uncertainty on FDI. This study was done in New York by selecting the East Asian Economies. They employ a sample of Indonesia, the Philippines, China, South Korea and Thailand. FDI inflows, current account balance, real exchange rate and exchange rate uncertainty used as variables. FDI used as dependent variable while rest of the variables as independent. First, they collect data then a panel co-integration test conducted, then developed and estimated an error correction model. This study finds that exchange rate volatility has favorable effect on FDI in the sample countries.

Ullah et al (2012) investigate the relationship of FDI with exchange rate and exchange rate volatility. This study was done in Pakistan by also using the Pakistani economic data. Sample employ the duration between 1980- 2010. Variables used in this study were FDI, inflation, trade openness, exchange rate and exchange rate volatility. Econometric techniques including volatility analysis, co-integration technique, unit root test and causality test used for had been applied for analysis of data. ARCH and GARCH techniques used to calculate the volatility. Findings of the study shows that Rupee depreciation positively relates with the FDI while exchange rate volatility negatively. Inflation affecting FDI positively but it is highly insignificant. The paper concluded with the policy recommendation is to reduce the exchange rate volatility and maintain the exchange rate in well-suited form.

Omakhanlen (2001) determine the effect of inflation and exchange rate on FDI and the relationship of FDI with economic growth. The main objective of this study is to hit upon the bidirectional influences among 
economic growth and FDI. This study was done in Nigeria. Major companies involved especially telecommunication companies. Data collected for the period of 1980 to 2009. He took Government expenditures and Gross fixed capital formation as Control variables to check the exaggerating of the estimated coefficient of FDI. Exchange rate and inflation used as independent variables, while FDI served as dependent variable.

OLS (ordinary least square) regression analysis conceded to determine the impact of Gross fixed Capital formation, FDI and Government expenditures on GDP. Findings shows that FDI has positive effect but statistically insignificant on GDP. It was also concluded that there is no effect of inflation on FDI, while exchange rate has an effect on FDI into the Nigerian economy for the period of (1980-2009). He concluded this study with the recommendation that the infrastructure of Nigeria must be developed to meet the requirements and needs of the foreign investors.

Nyarko et al (2011) took data from 1970 to 2008.the objective of this paper to examine the effect of exchange rate regime on FDI inflows for the sample of Ghana economy by applying co integration, OLS, error correction modeling approach. They took foreign direct investment as dependent variable and Democracy, exchange rate regime as independent variable. The results show that exchange rate regime and Democracy has no effect on FD. It shows that there is no relationship between FDI and exchange rate regime.

Chowdhury and Wheeler (2008) take the data from four developed countries. The aim of this paper to check the impact of shocks to exchange rate uncertainty (volatility) on foreign direct investment FDI for the sample of four countries Japan, Canada, US, UK by applying GARCH and VAR model approach. They took FDI as dependent variable and real output, price level, volatility of real exchange rate, interest rate, real exchange rate as independent variable. The result shows that exchange rate volatility has positive and significant impact on FDI. The effect is positive and significant in Canada, Japan and US.

Chaduhary et al (2012) took the annual data from 1980 to 2010. The objective of this paper to examine the effect of volatility exchange rate on foreign direct investment FDI for the sample of Asian economies by applying autoregressive distributed lag, GARCH approach, ARCH/GARCH mixed modeling approach. They take FDI as dependent variable and volatility exchange rate as independent variable. The result shows that there is positive and significant relationship between FDI and volatility exchange rate. The result shows the existence of long run and short run effect of volatility exchange rate and FDI in Asian economies.

Udomkerdmongkol and Morrissey (2008) take the data from 1990 to 2002. The aim of this paper to examine the impact of exchange rate on US foreign direct investment FDI for the sample of 16 emerging market countries by applying first- order auto consistent modeling approach. They take FDI as dependent variable and average official bilateral exchange rate, foreign investor, inflation, real exchange rate, confidence, manufacturing as a share of GDP as independent variable. The result shows that volatility has positive impact on FDI. It has positive relationship with the FDI.

Ahn (1998) focused on the effects of exchange rate policy and inflation on direct investment flows in developing countries. This was done in Indonesia by employing the data of twenty-three developing countries over the year 1970-1981. Real GDP, real GDP per capita, growth rate of real GDP, proxy for market size and prospective purchasing power and expectations of future growth respectively. These all variables used as independent variables. FDI used as dependent variable. Three models were used to analyze the data. He argued that inflation has significant negative effect on FDI inflow. With the change in exchange rate policies, inflation can reduce but can't be eliminated.

\section{Modeling FDI Determinants}

Arising from the literature (Udoh and Egwaikhide, 2008; Chowdhury and Wheeler, 2008; Currry, 2012, Ullah et al, 2008) a number of variables have been defined to form a regression model.

$\mathrm{FDI}=\beta_{0}+\beta_{1}(\mathrm{ER})+\beta_{2}(\mathrm{INF})+\beta_{3}(\mathrm{GDP})+\beta_{4}(\mathrm{VER})+\beta_{5}(\mathrm{GFC})+\beta_{6}(\mathrm{DOC})+\varepsilon$

Where;

FDI: Foreign direct investment, net inflows (\% of GDP)

ER: Real effective exchange rate index $(2005=100)$

INF: Inflation, GDP deflator (annual \%)

GDP: GDP growth (annual \%)

VER: exchange rate volatility

GFC: General government final consumption expenditure (\% of GDP)

DOC: Domestic credit to private sector (\% of GDP)

Market size and growth is one of the most important and key determinants of FDI. Large domestic market size makes scale economies, while emergent market improves the vision of the market potential. So, economy with huge market size attracts more FDI and countries with sustained and high growth rates receives more and more FDI flows than unstable economies. For the financial investors' products, real growth of GDP (GDP) confines the size of market. It provides as to determine the level of development of a country and thus reveals the purchasing power of an individual consumer. It is also used as a proxy for comparative profits on 
investment in different countries. It is admitted that if economic growth rate raises then real return to capital rises and therefore net FDI increases (Udoh and Egwaikhide, 2008). Domestic credit to private sector (DOC) is used as a parameter for the development of financial market. It is to be expected that it has positive effect on FDI. For the indication of size of government, general government final expenditures (GFC) is used as proxy, and expected to have positive relationship. Exchange rate volatility (VER) raises the uncertainty of product demand for the export leaning firms and may decrease the profitability of FDI (Udomkerdmongko and Morrissey, 2008).

\section{Data source and Methodology:}

The variables used in our study are FDI, inflation, exchange rate, exchange rate volatility, government final consumption and domestic credit. The data of all variables is gathered from World Bank Data, is a reliable source of data. All variables are used in log form which constructs interpretation more meaningful and robust. Volatility of exchange rate was expected using the GARCH modeling technique. It is admitted that GARCH model generate fine estimates of exchange rate volatility.

Nearly all economic variables are non-stationary at their plane form which formulates coefficients inconsistence and makes the empirical results unauthentic. There are meticulous methods are Augmented Dickey Fuller Test (ADF) and Phillips-Perron Test (PP) which neutralize the trouble of serial correlation of error terms.

\section{Results and Discussion}

As expected that most of the cases of economic time series, all variables of this study are nonstationary. ADF (Augmented Dickey Fuller) test has been applied for checking the stationary of data. ADF test confirmed that some of the variables are non-stationary in their level form but first difference of all the variables is stationary at $5 \%$ level of significance. Following table shows the level of significance of all variables.

Table 1Unit Root Test Results

\begin{tabular}{|l|l|l|l|l|}
\hline \multirow{2}{*}{ Variables } & \multicolumn{2}{|c|}{ Level } & \multicolumn{2}{c|}{ First Difference } \\
\cline { 2 - 5 } & T-statistics & Critical value & T-statistics & Critical value \\
\hline $\log (\mathrm{ER})$ & -2.960411 & -1.840202 & -2.963972 & -4.948998 \\
\hline $\log (\mathrm{GDP})$ & -2.960411 & -3.898156 & -2.971853 & -6.067491 \\
\hline $\log (\mathrm{GFC})$ & -2.960411 & -1.479343 & -2.963972 & -7.426515 \\
\hline $\log (\mathrm{INF})$ & -2.960411 & -3.593997 & -2.967767 & -7.255317 \\
\hline $\log ($ VER $)$ & -2.963972 & -10.98197 & -2.967767 & -18.10780 \\
\hline $\log (\mathrm{DOC})$ & -2.967767 & -2.976761 & -2.963972 & -3.735221 \\
\hline
\end{tabular}

Volatility series is making through GARCH (p, q) method and GARCH $(1,1)$ model is selected on the basis of AIC and SBC. Minimum values of AIC and SBC specify the significance of the model in illumination hetrocedasticity.

Table 2 Estimated Coefficients of Exchange Rate Volatility for Pakistan

\begin{tabular}{|c|c|c|}
\hline \multicolumn{3}{|c|}{$\operatorname{GARCH}(\mathbf{1}, 1)$} \\
\hline & Coefficient & $\rho$-value \\
\hline \multicolumn{3}{|c|}{ Mean Equation } \\
\hline $\mathrm{C}$ & 15.26442 & 0.0003 \\
\hline $\mathrm{ER}(-1)$ & 0.851456 & 0.0000 \\
\hline \multicolumn{3}{|c|}{ Variance Equation } \\
\hline $\mathrm{C}$ & 1.828874 & 0.1159 \\
\hline $\operatorname{RESID}(-1)^{\wedge} 2$ & -0.201204 & 0.0547 \\
\hline GARCH(-1) & 1.030447 & 0.0000 \\
\hline Akaike Info Criterion & 6.395739 & \\
\hline Schwartz Bayes Criterion & 6.239845 & \\
\hline
\end{tabular}

The next step is applying the Ordinary Least Square (OLS) on the data with AR (1) and AR (2) terms. Value of $\mathrm{R}^{2}$ shows that how much the model is fit for our selected variables. It must be greater than $50 \%$. And Prob. (F-stat) must be less than 5\% for significant results. Table 3 shows the result of OLS with ARMA terms.

Table 3 Regression Model

\begin{tabular}{|l|l|l|}
\hline Variables & Coefficient & Prob. \\
\hline DOC & 1.338285 & 0.1836 \\
\hline ER & 4.066208 & 0.0281 \\
\hline GDP & -0.022902 & 0.8317 \\
\hline GFC & 0.556464 & 0.2675 \\
\hline INF & -0.274812 & 0.0194 \\
\hline VER & -0.007237 & 0.0367 \\
\hline
\end{tabular}




\begin{tabular}{|l|l|l|}
\hline $\mathrm{C}$ & -16.19623 & 0.0614 \\
\hline $\mathrm{AR}(1)$ & 1.210614 & 0.0000 \\
\hline $\mathrm{AR}(2)$ & -0.309893 & 0.0698 \\
\hline R-square & 0.879418 \\
\hline Prob. (F-statistics) & 0.0000 \\
\hline Durbin-Watson stat & 2.323915 \\
\hline
\end{tabular}

Table shows that some of the variables are individually significant. $R^{2}=87 \%$ and Prob(F-stat $)=0.0000$ which identify that results are significant and model is more likely to be fit. Durbin-Watson $=2.323915$ stat indicates that there is no autocorrelation in the data.

$\mathrm{FDI}=1.3382 * \mathrm{DOC}+4.0662 * \mathrm{ER}-0.0229 * \mathrm{GDP}+0.5564 * \mathrm{GFC}-0.2748 * \mathrm{INF}-0.0072 * \mathrm{VER}-$ $16.1962+[\operatorname{AR}(1)=1.2106, \operatorname{AR}(2)=-0.3098]$

Above equation explains that exchange rate has positive relationship with FDI and it increases by units because of 1 unit increase in exchange rate. This positive relationship is in homogeny with Ullah et al (2012), Yasir et al (2012), Udomkerdmongkol and Morrissey (2008).

Exchange rate volatility (VER) is impacting FDI negatively. Udomkerdmongkol and Morrissey (2008), Ullah et al (2012), Udoh and Egwaikhide (2008), Ellahi (2011) found the same course of relationship. A unit increase in exchange rate volatility decreases the FDI of Pakistan by 0.0072 units. VER is highly significant at $5 \%$ level of significant as Prob. is less than 5\%. Inflation has negative effect on FDI and highly significant at 5\% level of significance. Udoh and Egwaikhide (2008), Kiat(2008) found the same direction of result towards FDI and inflation. Gross domestic product (GDP) negatively relates with FDI. It means a unit increase in GDP decreases the FDI of Pakistan by 0.0229 units but insignificantly.

\section{Residual diagnostics apply on the data and following results found:}

By applying Histogram test (Figure 1) for checking the normality of the data, as probability value is 0.6447 which is greater than $5 \%$, means data is normally distributed. Heteroskedasticity test (Breusch-PaganGodfrey) apply for measuring the heteroskedasticity (Table 6, a), the value of Prob. Chi square is greater than $5 \%$ i.e. 0.3396 . It shows that there is no heteroskedasticity in the data. Auto correlation (table $6, \mathrm{~b}$ ) shows that there is no auto correlation in the data because residuals are not spread from their mean variance.

\section{Conclusion Remarks}

In this study we have empirically examined the effect of exchange rate volatility on FDI in Pakistan. The estimated model captured into consideration two determinants of foreign investment in accordance with the literature. The finding show that exchange rate exhibited high volatility. Volatility in exchange rate increased the risk element and uncertainty facing foreign investors. Thus volatility in exchange rate and inflation negatively affect foreign investment in the Pakistan. This suggests that policy makers in Pakistan should chase macroeconomic stability and exchange rate in the country.

The result of the analysis also shows that the domestic policy commitment of policy makers that would increase the purchasing power of citizenry is to be anticipated. The diverse poverty reduction strategies should be appropriately managed to enhance the level of per capita income. This would result in attract the foreign investment and go ahead to the promotion of growth and development. It is also to be noted that government contribution in economic activities, mainly in production of private goods ought to be discouraged.

Unproductive state-owned ventures or enterprises which account for a reasonable proportion of government expenditures ought to be commercialized of privatized. It ought not to be glimpsed as an opportunity to further aggravate the unfairness in the country making the rich elites richer and the poor masses poorer.

\section{References}

[1]. Chaudhary, G., Shah, S., \& Bagram, M. (2012). Do Exchange Rate Volatility Effects Foreign Direct Investment? Evidence from Selected Asian Economies. Journal of Basic and Applied Scientific Research, 2090, 4304. Retrieved from http://www.textroad.com/pdf/JBASR/J.\%20Basic.\%20Appl.\%20Sci.\%20Res.,\%202(4)3670-3681,\%202012.pdf

[2]. Chowdhury, A. R. (2001). The impact of financial reform on private savings in Bangladesh. WIDER Discussion Papers//World Institute for Development Economics (UNU-WIDER). Retrieved from http://www.econstor.eu/handle/10419/53123

[3]. Del Bo, C. (2009). Foreign direct investment, exchange rate volatility and political risk. In ETSG annual conference. Retrieved from http://etsg.org/ETSG2009/papers/delbo.pdf

[4]. Dhakal, D., Nag, R., Pradhan, G., \& Upadhyaya, K. P. (2010). Exchange Rate Volatility And Foreign Direct Investment: Evidence From East Asian Countries. International Business \& Economics Research Journal (IBER), 9(7). Retrieved from http://www.journals.cluteonline.com/index.php/IBER/article/view/603

[5]. Ellahi, N. (2011). Exchange rate volatility and foreign direct investment (FDI) behavior in Pakistan: A time series analysis with auto regressive distributed lag (ARDL) application. African Journal of Business Management, 5(29), 11656-11661.

[6]. Kiat, J. (2010). The Effect of Exchange rate and inflation on Foreign Direct Investment and its relationship with economic growth in South Africa. University of Pretoria.

[7]. Lemi, A., \& Asefa, S. (2001). Foreign Direct Investment and Uncertainty: Implications for Ethiopia. Retrieved from http://scholarworks.wmich.edu/africancenter_icad_archive/20/ 
[8]. Nyarko, P. A., Nketiah-Amponsah, E., \& Barnor, C. (2011). Effects of exchange rate regimes on FDI inflows in Ghana. International Journal of Economics and Finance, 3(3), p277.

[9]. Omankhanlen, A. E. (2011). The Effect of Exchange Rate and Inflation on Foreign Direct Investment and Its Relationship with Economic Growth in Nigeria. Economics and Applied Informatics, (1), 5-16.

[10]. Osinubi, T. S., \& Amaghionyeodiwe, L. A. (2009). Foreign Direct Investment and Exchange Rate Volatility in Nigeria. International Journal of Applied Econometrics and Quantitative Studies, 9(2), 83-116.

[11]. RELATIONSHIP AMONG EXCHANGE RATE, F., \& EXCHANGE, F. (2012). INTERDISCIPLINARY JOURNAL OF CONTEMPORARY RESEARCH IN BUSINESS. Retrieved from http://journal-archieves23.webs.com/225-232.pdf

[12]. Udoh, E., \& Egwaikhide, F. O. (2008). Exchange rate volatility, inflation uncertainty and foreign direct investment in Nigeria. Botswana Journal of Economics, 5(7), 14-31.

[13]. Udomkerdmongkol, M., Görg, H., \& Morrissey, O. (2006). Foreign direct investment and exchange rates: A case study of US FDI in emerging market countries. Discussion papers in economics, School of Economics, Nottingham. Retrieved from http://www.econstor.eu/handle/10419/3831

[14]. ULLAH, S., HAIDER, S. Z., \& AZIM, P. (2012). IMPACT OF EXCHANGE RATE VOLATILITY ON FOREIGN DIRECT INVESTMENT. Pakistan Economic and Social Review, 50(2), 121-138.

\section{APPENDIX:}

Table 4:

\section{GARCH methodology:}

Dependent Variable: ER

Method: ML - ARCH (Marquardt) - Normal distribution

Date: 07/09/13 Time: 22:42

Sample (adjusted): 19812011

Included observations: 31 after adjustments

Convergence achieved after 49 iterations

Presample variance: backcast (parameter $=0.7$ )

$\mathrm{GARCH}=\mathrm{C}(3)+\mathrm{C}(4)^{*} \operatorname{RESID}(-1)^{\wedge} 2+\mathrm{C}(5)^{*} \mathrm{GARCH}(-1)$

\begin{tabular}{|c|c|c|c|c|}
\hline Variable & Coefficient & Std. Error & z-Statistic & Prob. \\
\hline $\mathrm{ER}(-1)$ & 0.851456 & 0.038115 & 22.33936 & 0.0000 \\
\hline $\mathrm{C}$ & 15.26442 & 4.211289 & 3.624644 & 0.0003 \\
\hline \multicolumn{5}{|c|}{ Variance Equation } \\
\hline $\mathrm{C}$ & 1.828874 & 1.163371 & 1.572047 & 0.1159 \\
\hline $\operatorname{RESID}(-1)^{\wedge} 2$ & -0.201204 & 0.104712 & -1.921494 & 0.0547 \\
\hline GARCH(-1) & 1.030447 & 0.190726 & 5.402759 & 0.0000 \\
\hline R-squared & 0.938567 & Mean dependent var & & 130.5822 \\
\hline Adjusted R-squared & 0.936449 & S.D. dependent var & & 41.31579 \\
\hline S.E. of regression & 10.41544 & Akaike info criterion & & 6.164451 \\
\hline Sum squared resid & 3145.963 & Schwarz criterion & & 6.395739 \\
\hline Log likelihood & -90.54899 & Hannan-Quinn criter. & & 6.239845 \\
\hline Durbin-Watson stat & 1.170239 & & & \\
\hline
\end{tabular}

Table 5:

OLS:

Dependent Variable: FDI

Method: Least Squares

Date: 07/09/13 Time: 22:54

Sample (adjusted): 19832011

Included observations: 29 after adjustments

Convergence achieved after 132 iterations

\begin{tabular}{crrrr}
\hline \hline Variable & Coefficient & Std. Error & t-Statistic & Prob. \\
\hline \hline DOC & 1.338285 & 0.971657 & 1.377322 & 0.1836 \\
ER & 4.066208 & 1.716907 & 2.368333 & 0.0281 \\
GDP & -0.022902 & 0.106333 & -0.215380 & 0.8317 \\
GFC & 0.556464 & 0.487862 & 1.140617 & 0.2675 \\
INF & -0.274812 & 0.108138 & -2.541321 & 0.0194
\end{tabular}




\begin{tabular}{lrrrr}
\multicolumn{1}{c}{ VER } & -0.007237 & 0.003232 & -2.239361 & 0.0367 \\
AR(1) & -16.19623 & 8.172800 & -1.981724 & 0.0614 \\
AR(2) & 1.210614 & 0.156907 & 7.715487 & 0.0000 \\
& -0.309893 & 0.161768 & -1.915669 & 0.0698 \\
\hline \hline R-squared & 0.879418 & Mean dependent var & -0.247966 \\
Adjusted R-squared & 0.831185 & S.D. dependent var & 0.809553 \\
S.E. of regression & 0.332622 & Akaike info criterion & 0.885505 \\
Sum squared resid & 2.212745 & Schwarz criterion & 1.309838 \\
Log likelihood & -3.839820 & Hannan-Quinn criter. & 1.018401 \\
F-statistic & 18.23276 & Durbin-Watson stat & 2.323915 \\
Prob(F-statistic) & 0.000000 & & \\
\hline \hline & & & \\
Inverted AR Roots & .84 & \\
\hline \hline
\end{tabular}

\section{Residual Diagonastics:}

Figure A:

A. Histogram test:

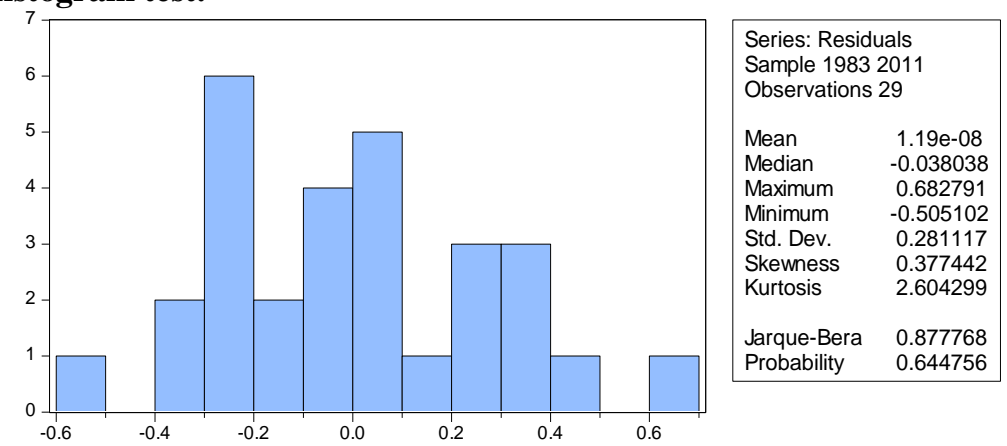

Table 6:

Heteroskedasticity Test: Breusch-Pagan-Godfrey

\begin{tabular}{llll}
\hline \hline & & \\
F-statistic & 1.123502 & Prob. F(6,22) & 0.3812 \\
Obs*R-squared & 6.801757 & Prob. Chi-Square(6) & 0.3396 \\
Scaled explained SS & 2.595018 & Prob. Chi-Square(6) & 0.8577 \\
\hline \hline
\end{tabular}

a. Heteroskedasticity test:

b. Auto correlation test

Date: 07/09/13 Time: 22:56

Sample: 19832011

Included observations: 29

Q-statistic probabilities

adjusted for 2 ARMA

term(s)

\begin{tabular}{|c|c|c|c|c|c|c|}
\hline Autocorrelation & Partial Correlation & & $\mathrm{AC}$ & PAC & Q-Stat & Prob \\
\hline.$|* *|$. &. $\mid * *$. & 1 & 0.348 & 0.348 & 3.8923 & \\
\hline$*$ & ***1. & 2 & -0.082 & -0.232 & 4.1178 & \\
\hline .1 & . $*^{*}$ & 3 & -0.014 & 0.123 & 4.1242 & 0.042 \\
\hline$* *$ & .**1. & 4 & -0.122 & -0.222 & 4.6616 & 0.097 \\
\hline .1 & $\left.\cdot\right|^{*} \cdot \mid$ & 5 & 0.010 & 0.206 & 4.6651 & 0.198 \\
\hline .1. & . * . & 6 & 0.062 & -0.114 & 4.8166 & 0.307 \\
\hline$*$. & * * . & 7 & -0.148 & -0.110 & 5.7081 & 0.336 \\
\hline$*$. & $* *$ & 8 & -0.184 & -0.118 & 7.1643 & 0.306 \\
\hline .1. &.$\left.\right|^{*}$ & 9 & -0.034 & 0.076 & 7.2151 & 0.407 \\
\hline .1. & .1 .1 & 10 & 0.030 & -0.017 & 7.2574 & 0.509 \\
\hline . * & . $* 1$ & 11 & -0.068 & -0.144 & 7.4857 & 0.587 \\
\hline$*$. & $* *$ & 12 & -0.183 & -0.159 & 9.2580 & 0.508 \\
\hline
\end{tabular}


c. Serial Correlation:

Breusch-Godfrey Serial Correlation LM Test:

\begin{tabular}{llll}
\hline \hline & & & \\
F-statistic & 0.700450 & Prob. F(2,18) & 0.5094 \\
Obs*R-squared & 2.094031 & Prob. Chi-Square(2) & 0.3510 \\
\hline \hline
\end{tabular}

